\title{
Estimating the Impact (Energy, Emissions and Economics) of the U.S. Fluid Power Industry
}

\section{December 2012}

\section{Prepared by}

Lonnie J. Love, Oak Ridge National Laboratory

Eric Lanke, National Fluid Power Association

Pete Alles, National Fluid Power Association

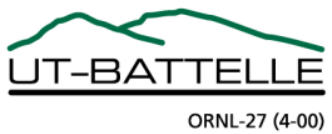




\title{
DOCUMENT AVAILABILITY
}

Reports produced after January 1, 1996, are generally available free via the U.S. Department of Energy (DOE) Information Bridge.

Web site http://www.osti.gov/bridge

Reports produced before January 1, 1996, may be purchased by members of the public from the following source.

\author{
National Technical Information Service \\ 5285 Port Royal Road \\ Springfield, VA 22161 \\ Telephone 703-605-6000 (1-800-553-6847) \\ TDD 703-487-4639 \\ Fax 703-605-6900 \\ E-mailinfo@ntis.gov \\ Web site http://www.ntis.gov/support/ordernowabout.htm
}

Reports are available to DOE employees, DOE contractors, Energy Technology Data Exchange (ETDE) representatives, and International Nuclear Information System (INIS) representatives from the following source.

Office of Scientific and Technical Information

P.O. Box 62

Oak Ridge, TN 37831

Telephone 865-576-8401

Fax 865-576-5728

E-mail reports@osti.gov

Web site http://www.osti.gov/contact.html

This report was prepared as an account of work sponsored by an agency of the United States Government. Neither the United States Government nor any agency thereof, nor any of their employees, makes any warranty, express or implied, or assumes any legal liability or responsibility for the accuracy, completeness, or usefulness of any information, apparatus, product, or process disclosed, or represents that its use would not infringe privately owned rights. Reference herein to any specific commercial product, process, or service by trade name, trademark, manufacturer, or otherwise, does not necessarily constitute or imply its endorsement, recommendation, or favoring by the United States Government or any agency thereof. The views and opinions of authors expressed herein do not necessarily state or reflect those of the United States Government or any agency thereof. 
ESTIMATING THE IMPACT (ENERGY, EMISSION AND ECONOMICS) OF THE U.S. FLUID POWER INDUSTRY

\author{
Lonnie J. Love, Ph.D., Oak Ridge National Laboratory \\ Eric Lanke, National Fluid Power Association \\ Pete Alles, National Fluid Power Association
}

December 2012

Prepared by

OAK RIDGE NATIONAL LABORATORY

Oak Ridge, Tennessee 37831-6283

managed by

UT-BATTELLE, LLC

for the

U.S. DEPARTMENT OF ENERGY

under contract DE-AC05-00OR22725 



\section{TABLE OF CONTENTS}

Title

Page

TABLE OF CONTENTS

iii

LIST OF FIGURES

$\mathrm{V}$

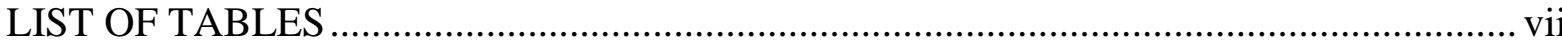

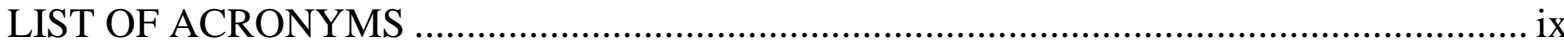

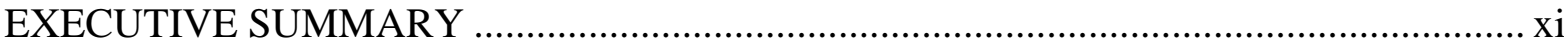

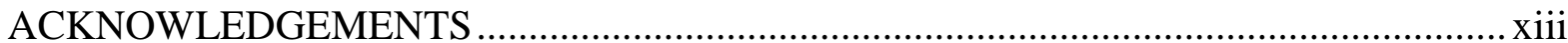

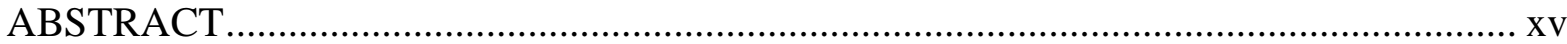

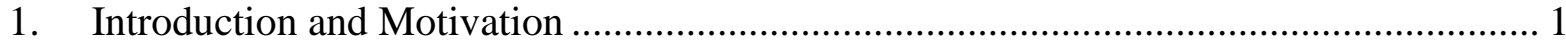

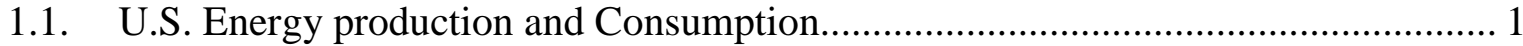

1.2. Economic and Environmental Cost of Energy ..................................................... 1

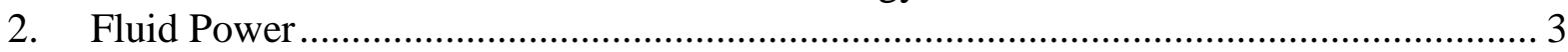

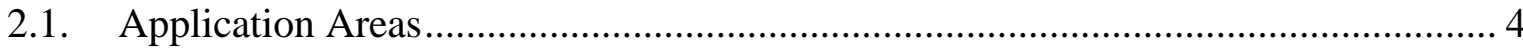

2.2. Why Do Companies Use Fluid Power?................................................................. 5

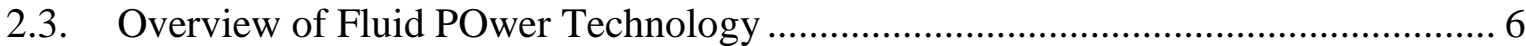

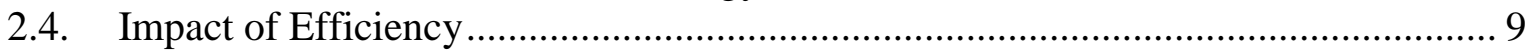

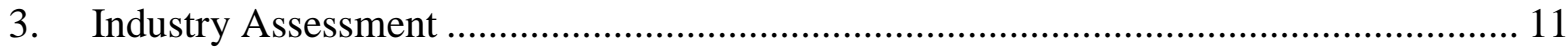

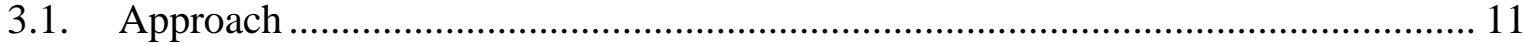

3.2. Mobile Hydraulics Energy Consumption............................................................... 11

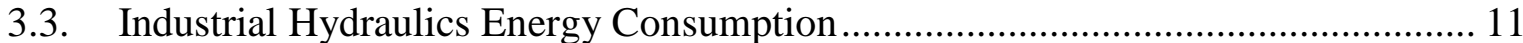

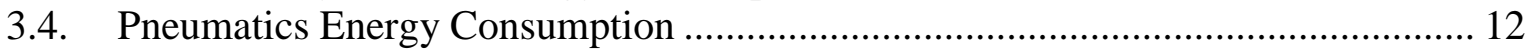

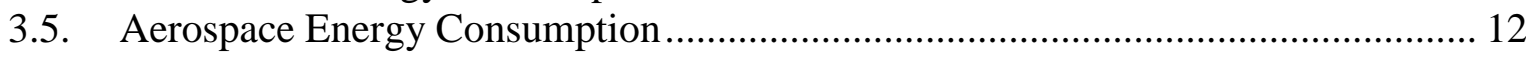

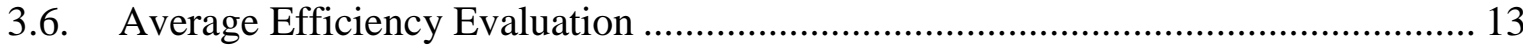

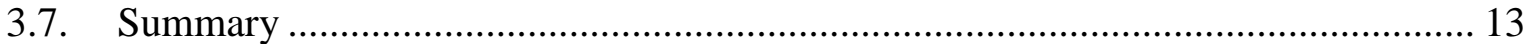

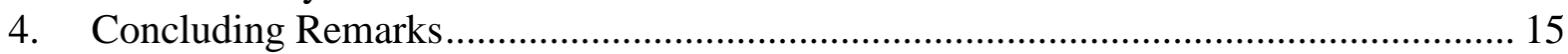

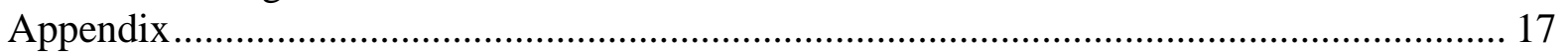

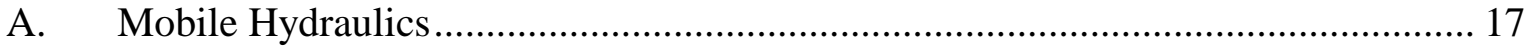

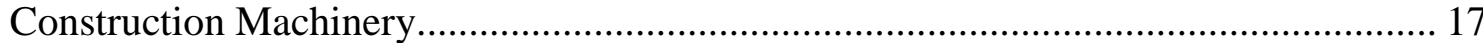

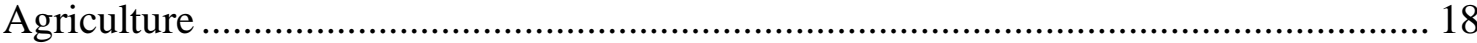

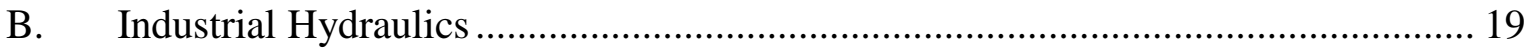

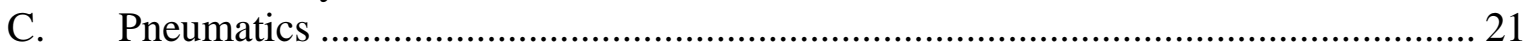

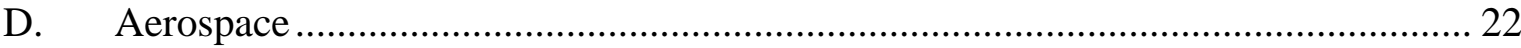

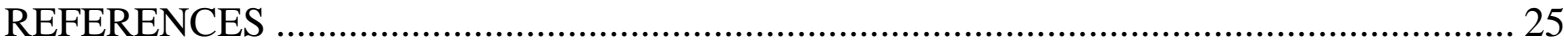




\section{LIST OF FIGURES}

Figure $\quad$ Page

Figure 1. Energy flow, 2010 (Quadrillion Btus) ....................................................... 1

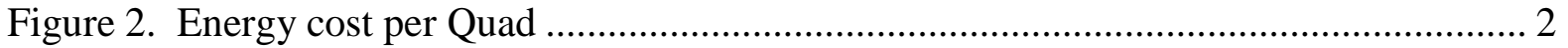

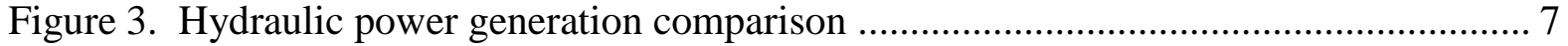

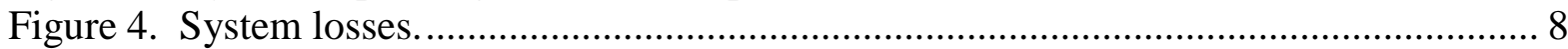

Figure 5. Energy losses in mobile load sensing (LS) hydraulic application......................... 8 


\section{LIST OF TABLES}

Table

Page

Table 1. Cost of Energy .

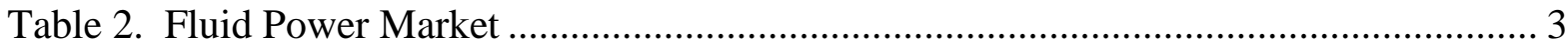

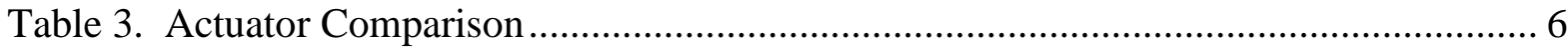

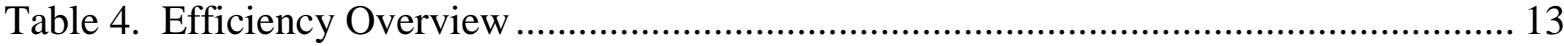

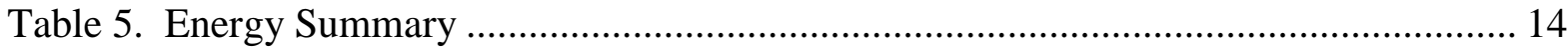

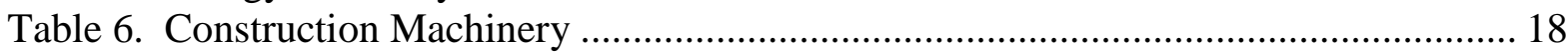

Table 7. Agriculture Energy Consumption ..................................................................... 19

Table 8. Injection Molding (IM) and Blow Injection Molding (BIM) Machines................. 20

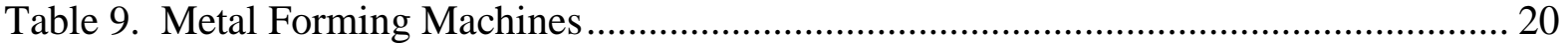

Table 10. Compressed Air and Pneumatics Energy Use ............................................... 22

Table 11. Aircraft Weight Distribution.......................................................................... 23 


\section{LIST OF ACRONYMS}

BIM - Blow Injection Molding

Btu - British Thermal Units

$\mathrm{CO}_{2}-$ Carbon Dioxide

DOE - U.S. Department of Energy

IM - Injection Molding

kWh - kilowatt hour

LS - Load Sensing

MMT - Million Metric Tons

NASA - National Aeronautic and Space Administration

NFPA - National Fluid Power Association

ORNL - Oak Ridge National Laboratory

Quad - Quadrillion $\left(10^{15}\right)$ Btus

R\&D - Research and Development

U.S. - United States 


\section{EXECUTIVE SUMMARY}

Fluid power (hydraulic and pneumatic actuation) is the generation, control, and application of pumped or compressed fluids when this power is used to provide force and motion to mechanisms. This form of mechanical power is an integral part of United States (U.S.) manufacturing and transportation. In 2008, according to the U.S. Census Bureau, sales of fluid power components exceeded $\$ 17.7 \mathrm{~B}$, sales of systems using fluid power exceeded $\$ 226 B$. As large as the industry is, it has had little fundamental research that could lead to improved efficiency since the late 1960 s (prior to the 1970 energy crisis). ${ }^{1}$ While there have been some attempts to replace fluid powered components with electric systems, its performance and rugged operating condition limit the impact of simple part replacement. Oak Ridge National Laboratory and the National Fluid Power Association (NFPA) collaborated with 31 industrial partners to collect and consolidate energy specific measurements (consumption, emissions, efficiency) of deployed fluid power systems. The objective of this study was to establish a rudimentary order of magnitude estimate of the energy consumed by fluid powered systems. The analysis conducted in this study shows that fluid powered systems consumed between 2.0 and 2.9 Quadrillion (10 ${ }^{15}$ ) Btus (Quads) of energy per year; producing between 310 and 380 million metric tons (MMT) of Carbon Dioxide $\left(\mathrm{CO}_{2}\right)$. In terms of efficiency, the study indicates that, across all industries, fluid power system efficiencies range from less than $9 \%$ to as high as $60 \%$ (depending upon the application), with an average efficiency of $22 \%$. A review of case studies shows that there are many opportunities to impact energy savings in both the manufacturing and transportation sectors by the development and deployment of energy efficient fluid power components and systems.

1 Discussion with Dr. Kim Stelson, director of NSF Center for Compact and Efficient Fluid Power

${ }^{2}$ Taken from http://www.eia.gov/totalenergy/data/annual/perspectives.cfm 


\section{ACKNOWLEDGEMENTS}

The results of this study would not have been possible without the commitment, devotion and cooperation of many people. The following is a list of the companies and contact personnel who provided critical information that served as the foundation for this report. Without their valuable insight and support, this report would not have been possible.

Matt Alles, ABB, Inc.

Rod Smith, Air Best Practices, Inc.

Jon Goreham, Alro Steel Group

Chris Parker, Baldor Electric

Scott Meldeau, Bimba Manufacturing Company

Berend Bracht, Bosch Rexroth Corp.

Scott Hibbard, Bosch Rexroth Corp.

Dennis Meckler, Bosch Rexroth Corp.

Gerald Graf, Ph.D., Caterpillar, Inc.

Randy Peterson, Caterpillar, Inc.

Jerry Wear, Caterpillar, Inc.

William Clippard, Jr., Clippard Instrument Laboratory

William Parks, Deltrol Fluid Products

Scott Krueger, Eaton Corp.

Daniel Cook, Enfield Technologies

R. Edwin Howe, Enfield Technologies

Mike Cybulski, Festo Corp.

Hans Zobel, Festo Corp.

Patrick Lee, Gates Corp.

Robert Mortenson, HUSCO International, Inc.

Joseph Pfaff, HUSCO International, Inc.

William Gorski, Mead Fluid Dynamics

David Geiger, Moog, Inc.

James Western, Pall Aeropower Corp.

Leonard Bensch, Ph.D., Pall Aeropower Corp.

Roger Sherrard, Parker Hannifin Corp.

Russell Strobach, Parker Hannifin Corp.

John Treharn, Parker Hannifin Corp.

Eric Battino, PepsiCo Corp.

Michael Scotese, Poclain Hydraulics

Andrea Vacca, Ph.D., Purdue University

Gregory Willard, Quality Control Corp.

Thomas Nelson, Racine Federated, Inc.

Frank Bowles, RHM Fluid Power

David Anderson, Sauer-Danfoss, Inc.

Tim Hansen, Sauer-Danfoss, Inc.

Jeff Herrin, Ph.D., Sauer-Danfoss, Inc.

William Scales, Scales Air, Inc. 
Niff Ambrisino, Scales Air, Inc.

Markus Schmider, Schmalz, Inc.

Volker Schmitz, Schmalz, Inc.

David DePasquale, Siemens, Inc.

Jon Jensen, SMC Corporation

Allen Carlson, Sun Hydraulics, Inc.

Craig Roser, Sun Hydraulics, Inc.

Judy Wojanis, Wojanis Supply, Inc. 


\begin{abstract}
This report provides an estimate of the energy, emissions and economic impact of the U.S. fluid power industry. Fluid power components and systems (hydraulics and pneumatics) are an integral part of U.S. manufacturing and transportation. The objective of this study was to:

- Quantify the economic impact of the fluid power industry. This includes sales of fluid power components and systems, magnitude of imports and exports and U.S. fluid power manufacturing jobs.

- Establish a rudimentary order of magnitude estimate of the energy consumed, average efficiency and emissions generated yearly by fluid power systems.
\end{abstract}

In 2008, sales of fluid power components exceeded $\$ 17.7 \mathrm{~B}$ and sales of systems using fluid power components exceeded $\$ 226 \mathrm{~B}$. For this study, the fluid power industry was organized into four main segments.

1. Mobile hydraulics - hydraulics used to perform tasks on mobile machines, such as construction equipment, earth-moving equipment, agricultural equipment, heavy trucks and buses.

2. Industrial hydraulics - hydraulics used to perform tasks in manufacturing facilities such as injection molding, material handling and metal forming.

3. Pneumatics - pneumatics used to perform tasks and processes in manufacturing and material handling facilities.

4. Aerospace - hydraulics and pneumatics used to perform tasks on airplanes, such as in landing gears and flight controls.

The results of the study show the following:

- Mobile hydraulics consumes between 0.4 and 1.3 Quads/year producing between 26 and $92 \mathrm{MMT}$ of $\mathrm{CO}_{2}$.

- Industrial hydraulic equipment consumes approximately 1.1 Quads/year producing 196 MMT of $\mathrm{CO}_{2}$ per year.

- Pneumatic equipment consumes approximately 0.5 Quads/year producing 90 MMT of $\mathrm{CO}_{2}$.

- Transportation of embedding hydraulic equipment in aerospace applications consumes approximately 0.02 Quads/year producing 1.7 $\mathrm{MMT}_{\text {of }} \mathrm{CO}_{2}$.

Therefore, the results of the study shows that, in 2008, fluid powered systems consumed between 2.0 and 2.9 Quads of energy producing between 310 and $380 \mathrm{MMT}$ of $\mathrm{CO}_{2}$. In terms of efficiency, the study indicates that, across all segments, fluid power system efficiencies range from less than $9 \%$ to as high as $60 \%$ (depending upon the application), with an average efficiency of $22 \%$. Case studies show that much of this energy is recoverable and there are tremendous opportunities for energy savings. 


\section{INTRODUCTION AND MOTIVATION}

\subsection{U.S. ENERGY PRODUCTION AND CONSUMPTION}

The United States consumes approximately 100 Quadrillion British Thermal Units (Quads) per year. Figure 1 shows that this energy is directed to four primary areas: residential housing, commercial buildings, industry and transportation. Fluid power is a critical form of actuation for the industrial and transportation industries that collectively account for 59 Quads/year. Unlike electric motors, fluid power systems have lower energy efficiency and the technology has seen little innovation in the past 40 years. Most fluid power research in the United States waned in the late 1960s and early 1970s, prior to the 1973 energy crisis. The objective of this study was to establish a rough estimate (i.e., order of magnitude) of the amount of energy consumed by fluid power systems and the impact improvements in efficiency can have on industry and the U.S. economy.

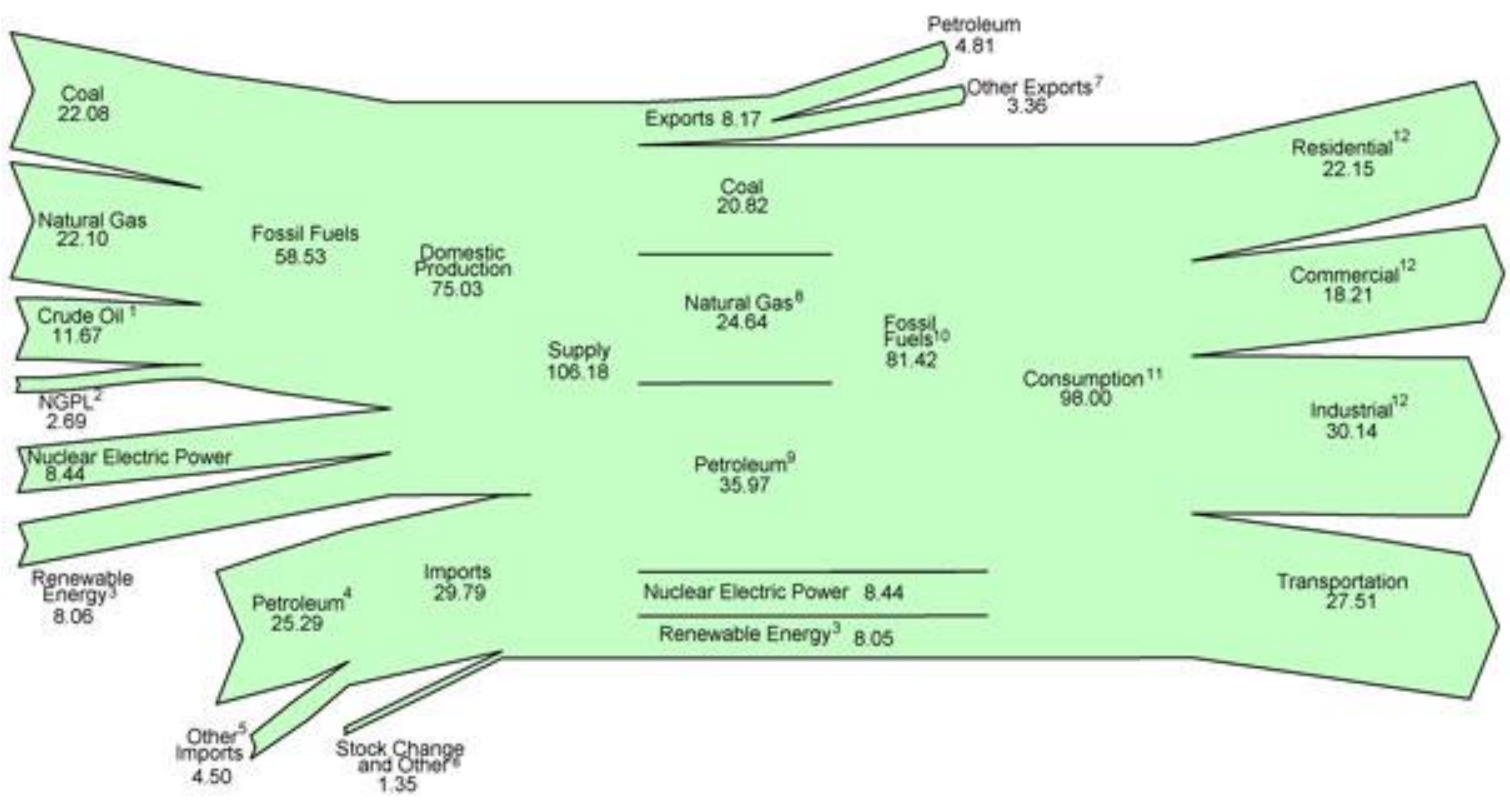

Figure 1. Energy flow, 2010 (Quadrillion Btus) ${ }^{2}$

\subsection{ECONOMIC AND ENVIRONMENTAL COST OF ENERGY}

The cost of energy varies with source and location. As an example, the average residential cost of electricity in 2009 varied from $9.07 \mathrm{c} / \mathrm{kWh}$ (West North Central Region) to $17.5 \mathrm{c} / \mathrm{kWh}$ (New England) with a national average of $11.55 \mathrm{c} / \mathrm{kWh}$. Industry rates over the same period varied from $5.72 \mathrm{c} / \mathrm{kWh}$ (West North Central Region) to $12.15 \mathrm{c} / \mathrm{kWh}$ (New England) with a national average of $6.84 \mathrm{c} / \mathrm{kWh}^{3}$ At $6.84 \mathrm{c} / \mathrm{kWh}$, one Quad of electricity

\footnotetext{
${ }^{2}$ Taken from http://www.eia.gov/totalenergy/data/annual/perspectives.cfm

${ }^{3}$ Taken from http://www.eia.doe.gov/emeu/steo/pub/cf tables/steotables.cfm?tableNumber=21
} 
costs $\$ 20.05 B$. In terms of emissions, the U.S. Energy Information Administration states that U.S. electrical power production produces, on the average, $1.341 \mathrm{lbs}$ of $\mathrm{CO}_{2}$ per $\mathrm{kWh}$. This translates to 178.2 million metric tons (MMT) of $\mathrm{CO}_{2}$ per Quad. ${ }^{4}$ Therefore, one Quad of electricity costs approximately $\$ 20 \mathrm{~B}$ producing $178 \mathrm{MMT}$ of $\mathrm{CO}_{2}$. For transportation, the average cost of diesel fuel in 2009 varied from \$2.28/gallon (Gulf Coast) to \$2.66/gallon (West Coast) with a U.S. average of $\$ 2.40 /$ gallon. ${ }^{5}$ Diesel fuel has an energy density of $138,700 \mathrm{Btu} / \mathrm{gallon}$. Therefore, one Quad of diesel fuel at \$2.40/gallon costs \$17B. Furthermore, 1 gallon of diesel produces $10.1 \mathrm{~kg}$ of $\mathrm{CO}_{2}$ which corresponds to $73 \mathrm{MMT}$ of $\mathrm{CO}_{2}$. Table 1 shows a general rule of thumb. One Quad of energy costs industry and consumers approximately $\$ 20 \mathrm{~B}$ and produces between 70 and $180 \mathrm{MMT}$ of $\mathrm{CO}_{2}$. Another important aspect of energy is cost volatility.

Table 1. Cost of Energy

\begin{tabular}{|c|c|c|c|}
\hline Source & Unit cost & Cost per Quad & Emissions per Quad \\
\hline Electricity & $6.84 \mathrm{c} / \mathrm{kWh}$ & $\$ 20 B$ & 178 MMT $\mathrm{CO}_{2}$ \\
\hline Diesel fuel & \$2.40/gallon & \$17B & $73 \mathrm{MMT} \mathrm{CO}_{2}$ \\
\hline
\end{tabular}

Figure 2 shows the cost variation of industrial electricity and diesel fuel over the past 16 years. It is clear that industries reliant on petroleum based energy sources have experience significant volatility in energy costs.

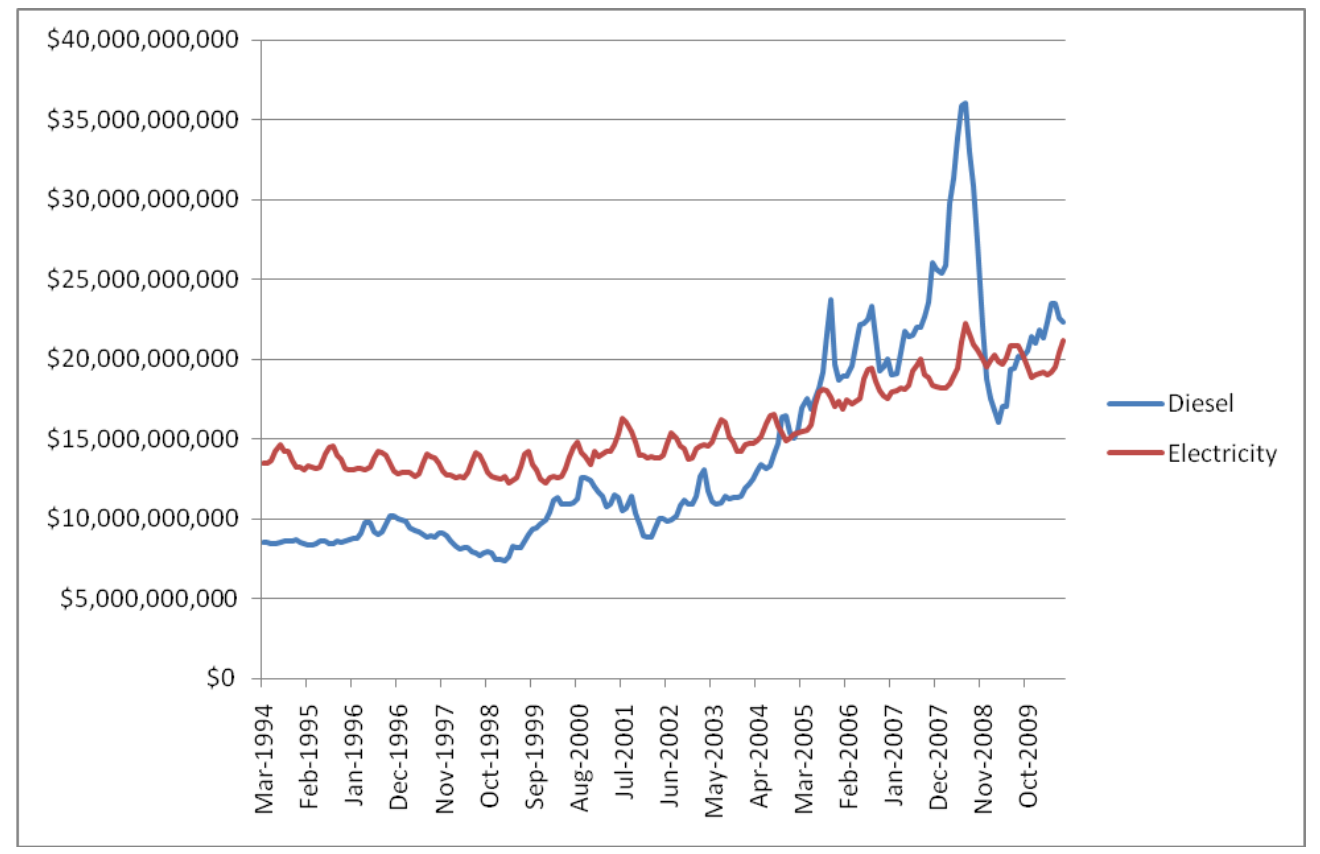

Figure 2. Energy cost per Quad ${ }^{6}$

\footnotetext{
${ }^{4}$ See U.S.EPA. 2000. Carbon Dioxide Emissions from the Generation of Electric Power in the United States, July, (http) ftp://ftp.eia.doe.gov/environment/co2emiss00.pdf

${ }^{5}$ http://www.eia.gov/dnav/pet/pet_pri_gnd_a_epm0_pte_cpgal_a.htm

${ }^{6}$ Data collected from http://www.eia.doe.gov/
} 


\section{FLUID POWER}

Fluid power is the generation, control, and application of pumped or compressed fluids (either liquids or gases) when this power is used to provide force and motion to mechanisms [1]. While fluid powered components are utilized in process controls (pumps and valves), this study focuses only on the use of liquids (hydraulics) and gases (pneumatics) for providing mechanical work. This is a large industry that not only manufactures hydraulic and pneumatic equipment, but also provides actuation that supports U.S. manufacturing and transportation. According to the U.S. Census Bureau, in 2008, U.S. sales of fluid powered components exceeded \$17.7B providing over 68,000 jobs, system sales exceed \$227B/year providing over 683,000 jobs. ${ }^{7}$ The data is summarized in Table 2.

Table 2. Fluid Power Market7

\begin{tabular}{|c|c|c|c|c|c|}
\hline $\begin{array}{l}\text { NAICS } \\
\text { Code }\end{array}$ & Name & Companies & $\begin{array}{l}\text { Shipments } \\
(\$ M)\end{array}$ & $\begin{array}{l}\text { Payroll } \\
(\$ M)\end{array}$ & Employees \\
\hline 332912 & Fluid power valves and hose fitting manufacturing & 384 & $\$ 8,639.68$ & $\$ 1,713.26$ & 34996 \\
\hline 333995 & Fluid power cylinder and actuator manufacturing & 324 & $\$ 5,180.98$ & $\$ 1,057.61$ & 20167 \\
\hline 333996 & Fluid power poump and motor manufacturing & 156 & $\$ 3,893.59$ & $\$ 671.27$ & 12885 \\
\hline Total & & 864 & $\$ 17,714.25$ & $\$ 3,442.14$ & 68048 \\
\hline \multicolumn{6}{|c|}{ Mobile hydraulics } \\
\hline 333111 & Agricultural implement manufacturing & 1153 & $\$ 21,728.73$ & $\$ 2,413.45$ & 54713 \\
\hline 333112 & Lawn and garden equipment manufacturing & 160 & $\$ 8,264.03$ & $\$ 707.26$ & 20544 \\
\hline 333120 & Construction machinery manufacturing & 825 & $\$ 37,458.80$ & $\$ 3,445.08$ & 72467 \\
\hline 333131 & Mining machinery manufacturing & 236 & $\$ 3,289.20$ & $\$ 525.60$ & 10925 \\
\hline 333132 & Oil and gas field machinery manufacturing & 664 & $\$ 17,738.54$ & $\$ 2,661.19$ & 48085 \\
\hline \multicolumn{6}{|c|}{ Industrial machinery } \\
\hline 333921 & Elevator and moving stairway manufacturing & 186 & $\$ 2,639.55$ & $\$ 414.33$ & 9504 \\
\hline 333922 & Conveyor equipment manufacturing & 853 & $\$ 7,852.19$ & $\$ 1,755.73$ & 35349 \\
\hline 333923 & Hoists and cranes manufacturing & 348 & $\$ 8,424.25$ & $\$ 1,100.67$ & 23945 \\
\hline 333924 & Industrial truck, tractor, traler and stacker machinery & 408 & $\$ 9,279.09$ & $\$ 1,174.01$ & 26683 \\
\hline 333512 & Machine tool (metal cutting) manufacturing & 389 & $\$ 5,621.45$ & $\$ 1,282.29$ & 21501 \\
\hline 333513 & Machine tool (metal forming) manufacturing & 198 & $\$ 1,521.24$ & $\$ 380.65$ & 7454 \\
\hline 333516 & Rolling mill machinery and equip. manufacturing & 61 & $\$ 738.42$ & $\$ 162.56$ & 2782 \\
\hline 333292 & Textile machinery manufacturing & 327 & $\$ 1,087.97$ & $\$ 249.83$ & 6146 \\
\hline 333210 & Sawmill and woodworking machinery manufacturing & 276 & $\$ 1,014.34$ & $\$ 244.77$ & 5444 \\
\hline 333291 & Paper industry machinery manufacturing & 255 & $\$ 2,548.19$ & $\$ 563.13$ & 10064 \\
\hline 333293 & Printing machinery and equipment manufacturing & 436 & $\$ 3,126.59$ & $\$ 726.71$ & 13155 \\
\hline 333294 & Food product machinery manufacturing & 514 & $\$ 4,243.65$ & $\$ 937.36$ & 17593 \\
\hline 333993 & Packaging machinery manufacturing & 586 & $\$ 4,671.38$ & $\$ 1,095.72$ & 19932 \\
\hline 333220 & Plastic and rubber industry machinery manufacturing & 524 & $\$ 3,677.20$ & $\$ 831.34$ & 17400 \\
\hline 333295 & Semiconductor machinery manufacturing & 225 & $\$ 14,287.89$ & $\$ 2,049.29$ & 25066 \\
\hline 333298 & All other industrial machinery manufacturing & 1406 & $\$ 9,653.81$ & $\$ 2,162.60$ & 42643 \\
\hline 336340 & Motor vehicle brake system manufacturing & 241 & $\$ 11,237.97$ & $\$ 1,156.49$ & 30434 \\
\hline \multicolumn{6}{|l|}{ Aerospace } \\
\hline 336413 & Other aircraft parts and auxiliary equipment & 890 & $\$ 30,098.94$ & $\$ 6,568.24$ & 112052 \\
\hline 336414 & Guided missile and space vehicle manufacturing & 28 & $\$ 16,323.39$ & $\$ 4,003.65$ & 49353 \\
\hline Total & & 11189 & $\$ 226,526.81$ & $\$ 36,611.95$ & 683234 \\
\hline
\end{tabular}

\footnotetext{
${ }^{7}$ http://www.census.gov/manufacturing/cir/historical_data/ma333n/index.html
} 


\subsection{APPLICATION AREAS}

The following is a partial list of application areas for fluid powered systems:

- Aerospace - Hydraulics provides light-weight compact actuation for flight control and landing gears.

- Agriculture - Hydraulics is used to provide mechanical power to tractors and their implements, excavators and field equipment.

- Automotive - Hydraulics is used in both the manufacturing (metal forming) as well as end products (power steering and brakes).

- Civil Engineering - Hydraulics enables the control of movable bridges, dams and hydropower facilities.

- Construction and Earth Moving Equipment - Hydraulics provides the mechanical power and rugged performance necessary for augers, excavators, loaders, bulldozers and utility vehicles to operate in the harsh outdoor environments.

- Entertainment - Fluid power is used to safely and smoothly control rides and simulators carrying people.

- Food Processing - Pneumatics provides the fast, reliable and rugged response necessary for the food processing industry.

- Forestry - Hydraulics is critical for log forwarders, skidders, grapples for loading and unloading heavy wood products.

- High Speed Rail - Hydraulic power provides the mechanical power to stabilize trains and the muscle to maintain the rails.

- Machine Tools - From chucks and clamps to covers and tool changers, hydraulic components and assemblies ensure reliable, economical operation in compact systems. Pneumatics is used in air guns, air tools, nail guns, etc. Almost every shop has a large supply of pneumatic tools.

- Material Handling - Hydraulics and pneumatics provide smooth and precision control to lift, load, carry and haul heavy loads.

- Medical Devices - Pneumatics for dental and surgical tools.

- Metal Forming - Hydraulic systems are necessary for press brakes, forge presses, hydroform presses, stamping presses, down acting presses along with horizontal and vertical balers.

- Military - Hydraulics is pervasive in military vehicles (e.g., Joint Light Tactical Vehicle, M915, M1-A1 Abrams Tank, Stryker, High Mobility Multi-purposed Wheeled Vehicles), aerospace (e.g., flight and ammunition controls for $\mathrm{CH} 47$ Chinook, OH58 Kiowa, Boeing C-17, F/A-18/F, V-22 Osprey.), marine (e.g., naval combat and marine vessels) and land operations (e.g., material handling, gun turrets).

- Mining - Hydraulics is vital for operating machinery below the earth's surface with its demanding sets of requirements related to fire resistance and compact construction for drilling/boring equipment, personnel carriers, transport vehicles and conveyors.

- Molding - Hydraulic actuation enables very high-force, precise motion duty-cycle intensive machines.

- Oil and Gas - Hydraulics is the actuation of choice for deep water and underground 
solutions (cylinders, heavy-duty pumps, high-pressure hoses, jack pumps, top dives, blow out preventers, iron roughnecks, winches and crane systems) for oil and gas exploration and production.

- Power Generation - Fluid power plays a vital role in the control of the heavy machinery that generates, distributes and delivers energy.

- Primary Metals - Hydraulics provides strength and ruggedness with an ability to work in extreme and hostile environments vital to reshape, form and move molten metal.

- Refuse - Hydraulics has traditional applications (moving and compacting refuse) but is finding new applications in the area of hybrid hydraulic vehicle control for stopand-go power assist to increase fuel economy.

- Truck and Bus - Hydraulics provide services to fan drives, power steering, brakes, vane pumps and fluid conveyance. Pneumatics is used on air brakes on buses, trucks and trains.

- Turf - Hydraulic turf machines are a growing market in noise-sensitive areas from golf courses to housing developments.

- Utility - Applications range from drill rigs and control of horizontal directional drills to the equipment used to maintain high power lines.

In terms of top-end use markets for hydraulics, end use as a percentage of total sales lists construction machinery (22.2\%), agriculture (21.2\%), material handling (5.4\%), mining, oil and gas field equipment (7.6\%), class 4-8/utility trucks (5.7\%), metal working and machine tools $(4.6 \%)$, paper, plastic and power generation $(6.1 \%)$ with the remaining $27.2 \%$ of the market going to other miscellaneous application areas. Likewise, the top-end use markets for pneumatics includes material handling $(11.9 \%)$, packaging machinery $(11.3 \%)$, metal and machine tools $(7.4 \%)$, food processing $(4.1 \%)$, and class $4-8$ trucks $(4 \%)$ with the remaining $61.3 \%$ going to other miscellaneous markets. ${ }^{8}$

\subsection{WHY DO COMPANIES USE FLUID POWER?}

All actuation technologies (motors and pistons) have advantages and disadvantages. The three primary sources of actuation in industry are electric, hydraulic and pneumatic motors and pistons. In general, electric motors are high speed, low force actuators whereas pneumatics and hydraulics are typically high force, low speed actuators. Many industrial applications require high force and low speed control of mechanical devices. Where weight is a concern, electric motors are composed of high density materials (rare earth magnetic, iron and copper) compared to low density fluids (water, oil and air) that are the primary motive force behind fluid power. For this reason, the power density of hydraulics (W/kg and $\mathrm{W} / \mathrm{m}^{3}$ ) is typically more than an order of magnitude superior to electrics. Table 3 provides a comparison of the metrics for many types of actuators [2][3][4]. Stress is the ratio of maximum actuator force to actuator cross section, strain is the ratio of actuator displacement to the overall actuator length, specific power provides the ratio of the peak power to the actuator weight, bandwidth is a measure of speed of response and stiffness is a measure of the load holding capabilities of the actuators.

\footnotetext{
${ }^{8}$ Market data from the National Fluid Power Association
} 
Table 3. Actuator Comparison

\begin{tabular}{ccccc}
\hline Actuator & $\begin{array}{c}\text { Strain } \\
(\%)\end{array}$ & $\begin{array}{c}\text { Stress } \\
(\mathrm{MPa})\end{array}$ & $\begin{array}{c}\text { Specific } \\
\text { Power } \\
(\mathrm{W} / \mathrm{kg})\end{array}$ & $\begin{array}{c}\text { Stiffness } \\
(\mathrm{MPa})\end{array}$ \\
\hline \hline Electromagnetic & 50 & 0.035 & 200 & 0.1 \\
Pneumatic & 50 & 0.69 & 200 & 0.1 \\
Hydraulic & 70 & 20.8 & 2000 & 1380 \\
\hline \hline
\end{tabular}

The high stress level for hydraulics and pneumatics, in comparison to electric motors, means that many fluid powered systems can directly drive a load (i.e. no need for gear reduction). The high specific power for hydraulics translates to low weight and volume, important for many mobile and industrial (limited floor space) applications. Pneumatic actuators have the advantages of low cost, ease of maintenance and cleanliness. Another advantage of fluid power systems is their shock tolerance. If a system is mechanically overloaded, pressure builds in the fluid and can be released with pressure relief valves, ensuring the system or environment is not damaged. There is no natural means for absorbing shock loads for an electric system. For this reason, fluid power systems are the actuation of choice in challenging and harsh environments. Pneumatics is also widely chosen for many industrial applications because they can be used safely in areas where there are spark hazards and for applications requiring wash-down for cleanliness such as food processing. The Achilles heel of fluid power is energy efficiency [5]. The British Fluid Power Association reported that downstream efficiency, excluding the compressor, of pneumatic systems is normally only $23 \%$ to $30 \%[6]$.

\subsection{OVERVIEW OF FLUID POWER TECHNOLOGY}

Industrial hydraulics and pneumatics are typically factory settings. The basic components consist of an electric motor driving a pump (hydraulics) or compressor (pneumatics). The fluid power is transmitted through pneumatic or hydraulic lines to the actuators. Flow control valves control the velocity or position of individual actuators performing the desired work. Mobile applications (mobile hydraulics and aerospace) are very similar but replace the electric motor with an internal combustion engine as the primary power source (see Figure $3)$. 


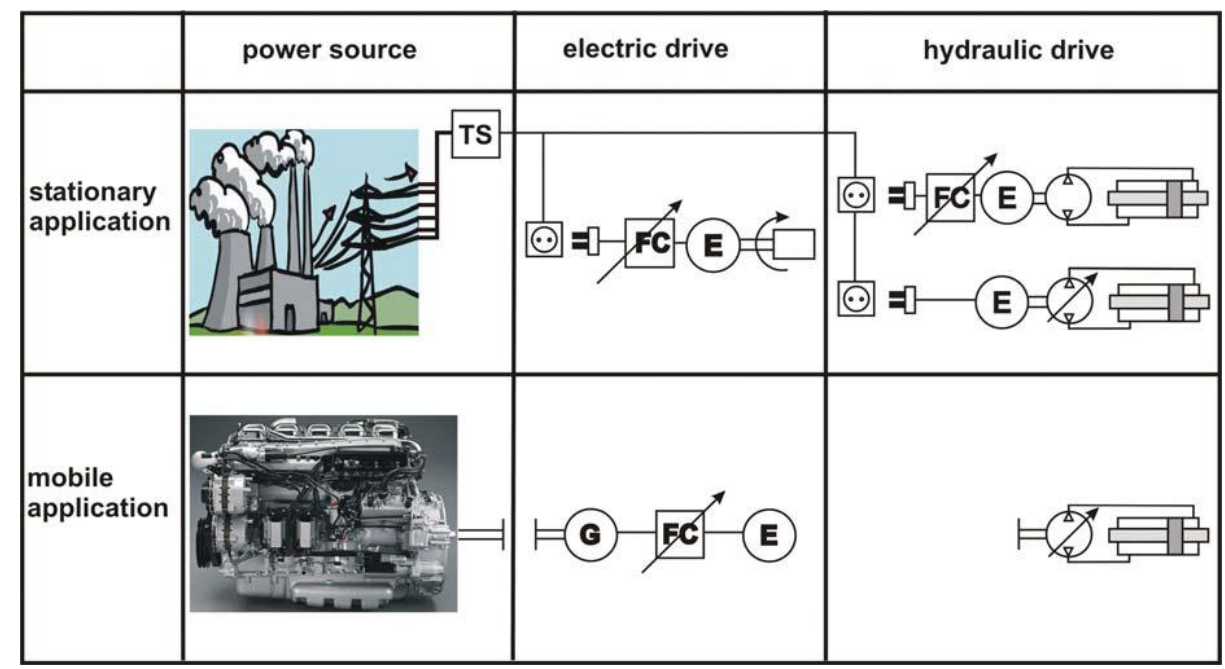

Figure 3. Hydraulic power generation comparison [7].

While there are a number of different architectures for delivering pneumatic and hydraulic power, Figure 4 illustrates the primary components that are useful in identifying sources of inefficiency. For mobile systems, there are parasitic losses associated with transmitting power from the engine to the pump. In addition, power to the load (material being moved) may not be steady but time varying, requiring dramatic variations in the power from the engine which impacts efficiency. There are also losses in the pump in the form of friction and internal leakage. While pump efficiency can be high under ideal conditions (approaching 90\%), efficiency when experiencing time varying loads can drop well below $75 \%$. Hoses and pipes transfer the pressurized fluid or gas to the actuators. In pneumatic systems, primary sources for line losses are leaks. For hydraulic systems, line losses are typically due to head losses associated with hoses and couplings. Control valves regulate the flow into, and out of, the actuators. Losses in the control valves include internal leakage in the valve (tare flow) as well as metering losses associated with pressure drops across the valves to control flow rate. This approach to control is much like using resistors to control electric motors. Furthermore, conventional spool valves are extremely limited in terms of power flow into, and out of, an actuator. For example, it takes hydraulic power to both raise and lower a load. For fixed pressure systems, it takes the same amount of energy to raise a light load as it does a heavy load (hydraulic energy $=$ pressure $*$ displaced fluid). When comparing force and speed, actuators can experience four quadrants of operation. When delivering power to a load, the actuator force is in the same direction as speed (actuator power is positive). There are likewise cases where the actuator is absorbing power from the load (actuator power is negative). In this case, the actuator can act like a pump taking power from the load redirecting power to the hydraulic power supply. With all of these losses compounding on each other, a typical mobile hydraulic powered systems have an overall efficiency of approximately $14 \%$ (see Figure 5). ${ }^{9}$

\footnotetext{
${ }^{9}$ Image provided by Dr. Monica Ivantysynova, College of Engineering, Purdue University.
} 


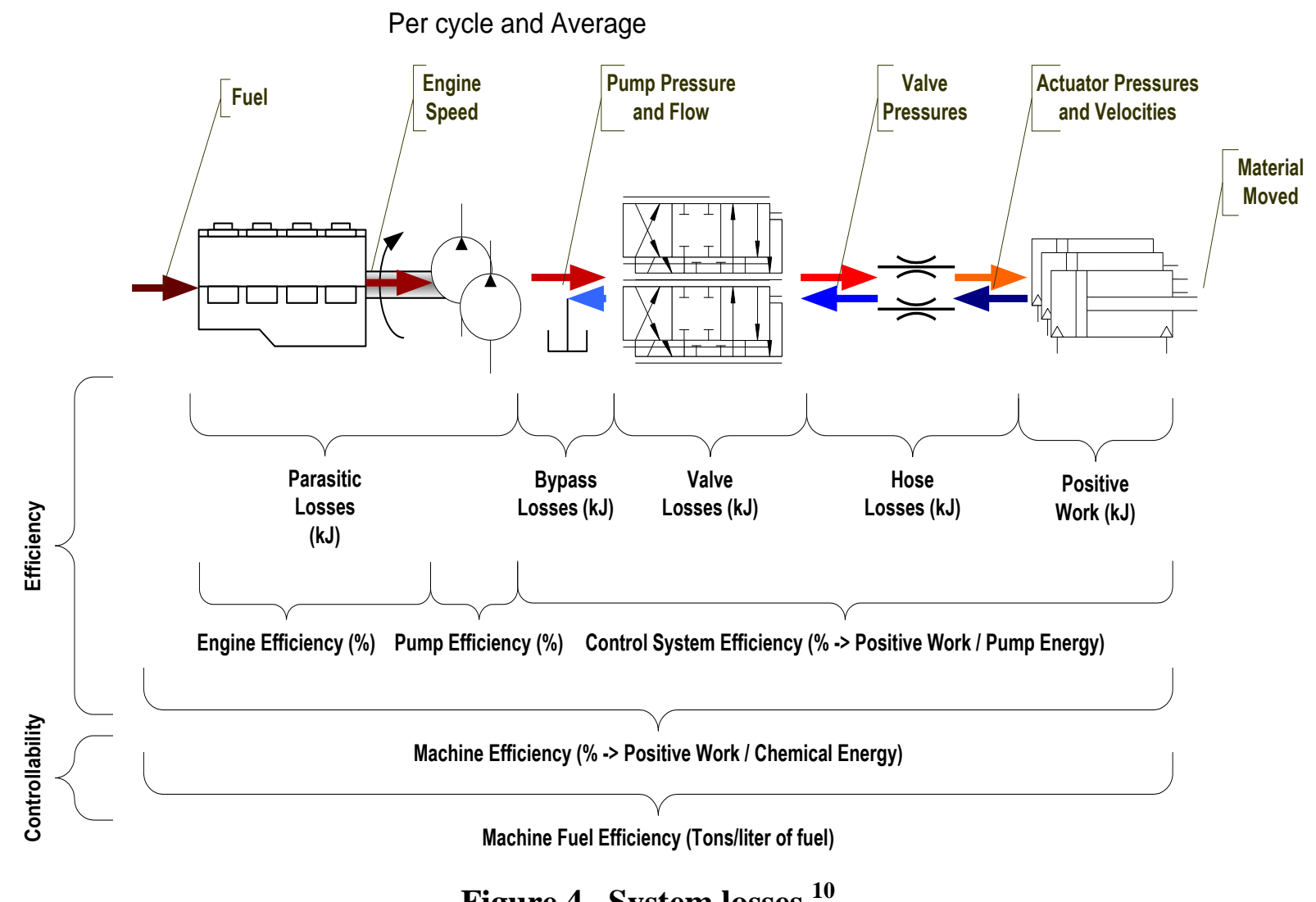

Figure 4. System losses. ${ }^{10}$

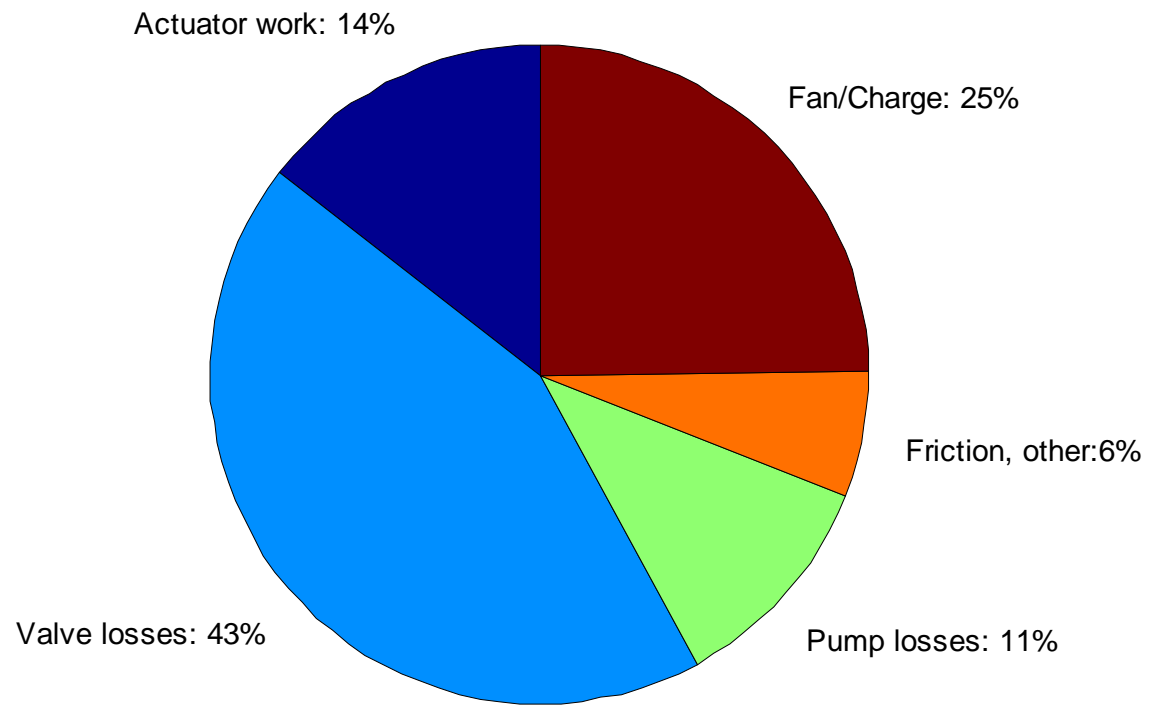

Figure 5. Energy losses in mobile load sensing (LS) hydraulic application. ${ }^{9}$

${ }^{10}$ Image provided by HUSCO International. 


\subsection{IMPACT OF EFFICIENCY}

This study shows that the fluid power industry consumes at least 2.0 Quads/year $\left(\mathrm{E}_{1}\right)$ with an average efficiency, $\eta_{1}$, of $22 \%$ (across all applications) producing 0.44 Quads of work (W in Eq. 1). For the same work, using the first law of thermodynamics, if the average efficiency increased to $27 \%$, the energy requirement $\left(\mathrm{E}_{2}\right)$ drops to 1.6 Quads saving approximately 0.4 Quads (see Eq. 2). Increasing the efficiency to $37 \%$ reduces the energy requirement to 1.2 Quads, saving approximately 0.8 Quads/year.

$$
\begin{gathered}
W=\eta_{1} \mathrm{E}_{1}=\eta_{2} \mathrm{E}_{2} \\
\Delta E=\mathrm{E}_{1}-\mathrm{E}_{2} \\
=\mathrm{E}_{1}\left(1-\frac{\eta_{1}}{\eta_{2}}\right)
\end{gathered}
$$

A series of case studies provide insight into the feasibility and magnitude of potential energy savings through both best practices and new design and control strategies.

Case 1: Load Sensing (LS) Systems - For constant pressure systems, the energy required to raise a light load (pressure times displaced actuator volume) is the same as the energy required to raise a light load. Liang and Virvalo show an efficiency increase in a hydraulic crane from $10.6 \%$ to $27.4 \%$ using LS pumps [5].

Case 2: Energy Recuperation - Conventional valve controlled systems use energy to both raise, and lower, a load. Palmberg is exploring mode switching and energy recuperation by replacing conventional spool valves with programmable valves that enable more flexibility in the direction of energy. His study suggests an additional 5\% to 10\% increase in efficiency [8]. This is reinforced by Liang and Virvalo who demonstrated an increase of efficiency from $27.4 \%$ with LS to $35.6 \%$ with programmable valves. An internal study by Incova showed a 10\% increase in fuel efficiency for an excavator during digging and an even greater benefit during grading.

Case 3: Hydraulic Transformers - Figure 5 shows that there are tremendous losses through the control valves. Throttling losses introduce both energy losses as well as generation of heat. There is growing interest in the area of valveless controls eliminating throttling losses. To achieve this goal, there must be a variable displacement actuator or hydraulic transformer [9],[10].

Case 4: Compressed Air - According to a recent Parker-Hannifin study, there are tremendous demand side opportunities for energy savings. Only $\$ 0.12$ to $\$ 0.17$ of every dollar spent on electricity to generate compressed air for pneumatic systems is doing useful work. ${ }^{11}$ Luo showed that recovery of exhaust power from pneumatic systems could increase efficiency by $14 \%$ to $23 \%$ [11].

11 Internal study conducted by Parker Hannifin. 
Case 5: Hybrid Hydraulics - Hybrid hydraulic systems size the primary power source for the average power demand and use hydraulic accumulators for energy storage. The accumulator can store energy during negative power flow (e.g., when a load is being lowered or a vehicle is braking) that can be efficiently used when accelerating or raising a load. Eaton demonstrated a 50\% improvement in fuel economy and $30 \%$ reduction in emissions by transforming a United Postal Service delivery truck to a hybrid hydraulic drive train [12].

Case 6: Weight Reduction - Eaton developed a new 5000 pounds per square inch hydraulic power system for the Airbus A380. The increased operating pressure reduced the overall weight of the hydraulic power system by a metric ton. ${ }^{12}$

These case studies show that much of the energy in fluid power is recoverable with both best practices and research focusing on energy efficient fluid power.

12 http://www.eaton.com/ecm/groups/public/@pub/@eaton/@corp/documents/content/pct_255356.pdf 


\section{INDUSTRY ASSESSMENT}

Oak Ridge National Laboratory (ORNL) and the National Fluid Power Association (NFPA) collaborated with 31 industrial partners to collect and consolidate energy specific measurements (consumption, emissions, efficiency) of deployed fluid powered systems. The objective was to provide a rough order of magnitude estimate of energy used on fluid powered systems.

\subsection{APPROACH}

Due to the diversity of the fluid power industry, the markets were segmented into four separate groups: mobile hydraulics, industrial hydraulics, pneumatics and aerospace. For each area, the objective was to estimate the energy consumed, emissions produced and average or range of efficiency. While it was impossible to collect data on all of the markets, the study includes data on many of the primary industries: injection molding, metal forming, pneumatics, aerospace, mining, agriculture and construction. In addition, while there is no data on the distribution of fielded equipment, there is a recent NFPA market report that estimates the relative size of each of these industries based on sales [13]. The energy consumed in each market was calculated based on measured data provided by industrial partners along with their respective market size. To project to the total energy in a segment, the total measured energy in each segment is divided by the industries' market share.

\subsection{MOBILE HYDRAULICS ENERGY CONSUMPTION}

For mobile hydraulics, data was collected from the agriculture and construction industries which collectively account for $69 \%$ of the mobile hydraulics industry. The analysis identified classes of equipment, population, fuel consumption rate, annual hours of use, percentage of power to hydraulics and the total efficiency. The energy consumed by these industries was 0.25 Quads. Therefore, the estimate of the energy consumed by the mobile fluid power industry is 0.36 Quads (0.25 Quads divided by 69\%). Another approach examined emissions from off-road vehicles and estimated the energy consumed driving fluid powered equipment was 1.26 Quads. The average efficiency in mobile hydraulic applications was $21.1 \%$. Therefore, mobile hydraulic systems consume between 0.36 and 1.26 Quads/year in energy.

\subsection{INDUSTRIAL HYDRAULICS ENERGY CONSUMPTION}

In industrial applications, hydraulics is used to control industrial machinery. Applications include bailers and compactors, hydraulic presses, industrial machinery, machine tooling, paper, plastic and rubber processing, pressure diecasting machines, medical equipment, oil and gas refining, and power generation. Industrial hydraulics is ideal for the harsh environment because of their exceptional tolerance to contamination and high temperatures. For the industrial hydraulic market, data was collected from the injection molding and machine tool industries. These two industries represent $17.3 \%$ of the total industrial hydraulics industry. A sampling of this industry shows that there are approximately 103,700 
injection molding machines in the United States consuming approximately 0.18 Quads of energy each year. There are approximately 160,000 metal forming machines consuming approximately 0.010 Quads/year. The total industrial hydraulics industry consumes approximately 1.10 Quads of energy per year producing approximately $196.12 \mathrm{MMT}$ of $\mathrm{CO}_{2}$.

\subsection{PNEUMATICS ENERGY CONSUMPTION}

Pneumatics, like hydraulics, is pervasive in industry but is based on 1960s' technologies. Pneumatics accounts for a tremendous amount of energy in manufacturing. Seventy percent of all manufacturing facilities in the United States have some form of compressed air systems. Most of these systems provide compressed air to drive a variety of equipment including machine tools, manufacturing and material handling equipment. A recent internal analysis based on data from the Department of Energy's (DOE's) Compressed Air Challenge of more than 203,000 industrial plants using pneumatics, shows a potential annual savings of $\$ 2.34 \mathrm{~B}$ in electricity costs through optimization of plant air production and productivity enhancements. This report assumed $\$ 0.08 / \mathrm{kWh}$ energy cost. Therefore, this energy savings is equivalent to 0.10 Quads through Best Practices. Furthermore, the Compressed Air Challenge states that these direct improvements using today's technologies account for only $25 \%$ of the known losses suggesting a total loss of 0.40 Quads due to inefficiencies in pneumatic systems. Today, the typical efficiency for industrial pneumatic systems is between $12 \%$ and $17 \%$ [6]. Therefore, a conservative estimate of the total energy devoted to pneumatics is 0.5 Quads/year assuming these losses account for $85 \%$ of the total energy devoted to pneumatics assuming an average efficiency of $15 \%$.

\subsection{AEROSPACE ENERGY CONSUMPTION}

The aircraft industry has two primary segments: passenger and cargo. The U.S. Department of Transportation estimates that passenger air transport consumed 18,854 million gallons of fuel totaling 2.393 Quads of energy and producing $200 \mathrm{MMT}$ of $\mathrm{CO}_{2}$ in 2008 (Table 2.6 in the Transportation Energy Databook). Cargo accounted for 15,146 million ton-miles of freight. Fuel efficiency for freight is measured in Btu/ton-mile. The fuel economy for aircraft varies significantly. ${ }^{13}$

The focus on energy due to fluid power for the aerospace industry was the energy used to transport the embedded fluid powered components in aircraft. Hydraulics and pneumatics is vital for the aerospace industry in terms of flight control surfaces and landing gear. A study, conducted by the National Aeronautics and Space Administration (NASA) for the All Electric Aircraft Program, estimated that embedded hydraulic components accounted for $9.5 \%$ of the fuel used on an aircraft [14]. An analysis of the weight distribution of aircraft shows that hydraulic and pneumatic equipment represents between $0.71 \%$ and $1.34 \%$ of the weight in an aircraft with an average of $0.98 \%$. In 2008, the aerospace industry (commercial and cargo) consumed approximately 2.39 Quads of energy (according to the 2010 Transportation Energy Data Book), 0.024 Quads devoted to transporting the embedded fluid powered components.

${ }^{13}$ http://www.icao.int/icaonet/cnfrst/CAEP/CAEP SG 20082/docs/Caep8 SG2 IP11.pdf 


\subsection{AVERAGE EFFICIENCY EVALUATION}

The efficiency of fluid powered systems varies significantly from application to application. To establish an average efficiency across all sectors that would be useful for energy savings estimates, this analysis applied an energy weighting function for each sector to establish an overall average. The analysis only includes known data. For the industrial applications, the typical energy efficiency of the fluid powered system is 50\%. For mobile hydraulic applications (construction, mining and agriculture) the average efficiency was $21 \%$. For pneumatic applications, the average efficiency was $15 \%$. Table 4 shows the weighed energy efficiency for the entire fluid power industry was $22 \%$.

Table 4. Efficiency Overview

\begin{tabular}{|l|l|l|l|}
\hline Sector & Energy & Efficiency & Weighted Efficiency \\
\hline Mobile & 0.25 & $21 \%$ & $5 \%$ \\
\hline Industrial Hydraulics & 0.18 & $50 \%$ & $9 \%$ \\
\hline Pneumatics & 0.50 & $15 \%$ & $8 \%$ \\
\hline \multirow{2}{*}{} & Total & $22 \%$ \\
\hline
\end{tabular}

\subsection{SUMMARY}

Table 5 provides a summary of the estimated energy and emissions for our four target industries: mobile hydraulics, industrial hydraulics, aerospace and pneumatics. The total energy consumed by fluid power ranges between 2.0 and 2.9 Quads/year producing between 308 and $380 \mathrm{MMT}$ of $\mathrm{CO}_{2} /$ year. The average efficiency of these systems is $22 \%$. The National Fluid Power Association conducted a workshop in 2010 focusing on energy efficiency. Subject matter experts from eighteen fluid power manufacturers projected that a 5 year effort focusing on Best Practices could increase this efficiency by $5 \%$ to an average efficiency of $27 \%$. Best Practices consists of conducting energy audits of manufacturing facilities and identifying energy savings possible with the deployment of existing technologies. Using the formula shown in Equation 2, the impact of this improvement (increasing efficiency from $22 \%$ to $27 \%$ for an industry that consumes more than 2.0 Quads) would save U.S. industry and consumers approximately 0.4 Quads/year. This group also projected that a more aggressive 15 year research and development (R\&D) effort, focusing on sensing, design, controls and advanced materials could increase this efficiency by $15 \%$ to an average efficiency of 37\%. The impact of this long-term improvement, using Equation 2 with an efficiency improvement from $22 \%$ to $37 \%$ for an industry consuming more than 2.0 Quads, would save U.S. industry and consumers approximately 0.8 Quads/year. 
Table 5. Energy Summary

\begin{tabular}{|c|c|c|c|c|c|c|c|}
\hline \multirow{2}{*}{$\begin{array}{l}\text { Sector } \\
\text { Mobile Hydraulics }\end{array}$} & \multicolumn{2}{|c|}{ Energy (Quads) } & \multirow[t]{2}{*}{ Market \% } & \multicolumn{2}{|c|}{$\begin{array}{l}\text { Fuel (billion } \\
\text { gallons) }\end{array}$} & \multicolumn{2}{|c|}{ CO2 (MMT) } \\
\hline & Low & High & & Low & High & Low & High \\
\hline Agriculture & 0.016 & & $33.65 \%$ & 0.11 & & 1.15 & \\
\hline Construction & 0.233 & & $35.24 \%$ & 1.68 & & 16.98 & \\
\hline Sub Total & 0.249 & & $68.89 \%$ & 1.80 & & 18.13 & \\
\hline Total Mobile Hyd. & 0.362 & 1.260 & & 2.61 & 9.08 & 26.32 & 91.728 \\
\hline \multicolumn{8}{|l|}{ Industrial Hydraulics } \\
\hline Injection Molding & 0.181 & & $4.86 \%$ & & & 32.37 & \\
\hline Metal Forming & 0.009 & & $12.43 \%$ & & & 1.55 & \\
\hline Sub Total & 0.190 & & $17.30 \%$ & & & 33.92 & \\
\hline Total Industrial Hyd. & 1.096 & 1.096 & & & & 196.12 & 196.12 \\
\hline Aerospace & 0.024 & 0.024 & & 0.170 & 0.170 & 1.71 & 1.71 \\
\hline Total Hydraulic & 1.48 & 2.38 & & & & & \\
\hline Pneumatics & 0.50 & 0.50 & & & & 84.12 & 91.11 \\
\hline Total & 1.98 & 2.88 & & 2.78 & 9.25 & 308.27 & 380.67 \\
\hline
\end{tabular}




\section{CONCLUDING REMARKS}

Fluid power (hydraulics and pneumatics), is a fundamental technology with unique capabilities. It is used pervasively in applications of great importance such as transportation, construction, agriculture, manufacturing, aerospace, and medical devices. Although a large consumer of energy, the technology is also typically low in energy efficiency. While there have been some attempts to replace fluid power with higher efficiency electric systems, fluid power's high performance and rugged operating condition limit the impact of simple part replacement. Therefore, there are tremendous opportunities to improve efficiency through both Best Practices and a focused R\&D program. Data from our industrial partners shows that the fluid power industry consumes between 2.0 and 2.9 Quads of energy per year. The average efficiency of fluid powered systems is $22 \%$. Near-term ( 5 year) solutions based on energy audits and implementation of Best Practices has the potential of saving of approximately 0.4 Quads/year. Long-term (15 year) solutions based on exploring energy efficient fluid powered components and systems can save approximately 0.8 Quads/year. Case studies, as described in this report, reinforce the efficiency estimates and the potential for energy savings and recovery. 


\section{APPENDIX}

\section{A. MOBILE HYDRAULICS}

For the mobile hydraulics industry, data was collected from the construction and agriculture industries. These two industries account for $69 \%$ of the total mobile hydraulics industry. Data included classes of equipment, population, fuel consumption rate, annual hours of use, percentage of power to hydraulics and the total efficiency. The product of the population, hours of use, average fuel consumption rate (gallons/hour), assume a 35\% engine efficiency, and percentage of power going to hydraulics provided an estimate of the gallons of diesel consumed each year. The analysis shows that the entire mobile hydraulics industry consumes more than 2.61 billion gallons of fuel, 0.36 Quads of energy, producing more than 26.32 MMT of $\mathrm{CO}_{2}$. Another point for comparison is a 2004 study on off-highway transportation related fuel use. A large portion of off-road equipment (30.3\% construction, $19.9 \%$ agriculture, $30.3 \%$ industrial) uses fluid power that consumed approximately 2.58 Quads in 2001 [15]. HUSCO International examined fuel consumption and emissions from off-road vehicles and estimated the energy consumed driving fluid powered equipment was 1.26 Quads. ${ }^{14}$

\section{Construction Machinery}

The U.S. construction and mining machinery manufacturing industry consists of approximately 1200 companies employing more than 105 million people with a combined U.S. industry revenue exceeding \$36B. ${ }^{15}$ Major U.S. companies include Caterpillar, Deere, Terex and Manitowoc Crane and Joy Global, Inc. (one of the world's largest manufacturers of underground mining machinery). Construction machinery is dominated by ten types of equipment: backhoes, bulldozers, construction and surface mining rock drill bits, construction tractors and attachments, off-highway trucks, pile-driving equipment, portable crushing, pulverizing and screening machinery, power post hole digging machinery, motor graders and paving machinery, and surface mining machinery. Typically, these machines have large diesel engines that provide mechanical power to a hydraulic power unit that likewise provides hydraulic power to the wheels and/or actuators to move a load. In some cases (typically where reverse motion is minimized), a mechanical transmission provides power for locomotion. However, large-scale construction equipment used fluid power for both driving the wheels as well as controlling implements. A summary of the results are displayed in Table 6. The table accounts for the percentage of energy devoted to the hydraulic components. Construction equipment consumes over 2.67 billion gallons of fuel. After accounting for the engine losses and percentage of power going to hydraulics, hydraulic components consume approximately 0.23 Quads of energy per year. The overall hydraulic system efficiency ranges from $13 \%$ to $35 \%$.

\footnotetext{
${ }^{14}$ HUSCO International's analysis was based on the NONROAD EPA tool, extracting hydraulic equipment and estimating the percentage of energy devoted to fluid power on those systems.

${ }^{15}$ http://www.trade.gov/mas/manufacturing/OAAI/ag equipment snapshot.asp
} 
Table 6. Construction Machinery

\begin{tabular}{|c|c|c|c|c|c|c|c|}
\hline Equipment & Quantity & Hours/yr & Gal/hr & $\begin{array}{l}\text { Total Fuel } \\
\text { (gallons) }\end{array}$ & $\begin{array}{l}\text { Fuel to Hyd. } \\
\text { (gallons) }\end{array}$ & $\begin{array}{l}\text { Hydraulic } \\
\text { Efficiency }\end{array}$ & $\begin{array}{l}\text { Energy } \\
\text { (Quads) }\end{array}$ \\
\hline Excavators & 124544 & 1092 & 5.73 & $7.79 \mathrm{E}+08$ & $6.230 \mathrm{E}+08$ & $35 \%$ & $8.641 \mathrm{E}-02$ \\
\hline Rough Terrain Forklifts & 110678 & 662 & 0.91 & $6.64 \mathrm{E}+07$ & $1.660 \mathrm{E}+07$ & $16 \%$ & $2.303 \mathrm{E}-03$ \\
\hline Rubber Tire Loaders & 137811 & 761 & 8.08 & $8.48 \mathrm{E}+08$ & $4.238 \mathrm{E}+08$ & $35 \%$ & $5.878 \mathrm{E}-02$ \\
\hline Loaders/Backhoes & 332269 & 1135 & 1.36 & $5.13 \mathrm{E}+08$ & $3.076 \mathrm{E}+08$ & $22 \%$ & $4.266 \mathrm{E}-02$ \\
\hline Aerial Lifts & 62102 & 384 & 0.88 & $2.09 \mathrm{E}+07$ & $1.043 \mathrm{E}+07$ & $13 \%$ & $1.447 \mathrm{E}-03$ \\
\hline Cranes & 32424 & 990 & 3.03 & $9.73 \mathrm{E}+07$ & $1.945 \mathrm{E}+07$ & $13 \%$ & $2.698 \mathrm{E}-03$ \\
\hline Skid Steer Loaders & 517076 & 818 & 0.83 & $3.51 \mathrm{E}+08$ & $2.806 \mathrm{E}+08$ & $16 \%$ & $3.891 \mathrm{E}-02$ \\
\hline & & & Total & $2.67 \mathrm{E}+09$ & $1.681 \mathrm{E}+08$ & $21 \%$ & 2.332E-01 \\
\hline
\end{tabular}

\section{Agriculture}

Another large segment of mobile fluid power applications is the agriculture industry. The majority of fluid powered agriculture equipment is in the area of large (> $100 \mathrm{hp})$, medium (> $40 \mathrm{hp}$ ) and small tractors ( $<40 \mathrm{hp})$ and combines. Tractors serve as the general tool for transporting and powering (mechanically and hydraulically) cultivating equipment. Hydraulics provide power for the brakes and steering, for implements, selective control valves control the power for raising and lowering parts as well as providing power to motors for mechanical movement. Hydraulic systems today are much more precise and safer than power take offs (PTOs) and can be used to control devices such as variable-rate planters or hydrostatic drive systems. Manufacturers have increased the capacity of hydraulic systems on tractors (up to $90 \mathrm{gpm}$ ) as well as increased the electronic controls to allow many more functions to be performed hydraulically. Fine motion control is enabling auto-guided steering technology. ${ }^{16}$

In 2007, the United States had 2,204,792 farms covering approximately 226 million acres with receipts exceeding \$370B. The U.S. farm equipment manufacturing industry includes approximately 1000 companies, employing more than 50,000 people with a global market of $\$ 70 \mathrm{~B}$ with U.S industry shipments of $\$ 32.7 \mathrm{~B}$. Major products include tractors, self-propelled harvesting combines, tractor attachments, planting and fertilizing equipment, harvesting, hay and mowing machinery, dairy and poultry equipment, sprayers and irrigation equipment and commercial turf and ground care equipment. The 50 largest companies, such as Deere, AGCO and Case New Holland, produce more than $80 \%$ of the revenue. United States sales of tractors and combines totaled $\$ 11.5 \mathrm{~B}$ in 2008. Because of the rugged use and need for long service life of many farm machines, the industry relies heavily on fluid power equipment. Energy use in agriculture includes direct use (for operating machinery and equipment) and indirect use (for producing fertilizers and pesticides produced off the farm). In 2005, agriculture accounted for approximately 0.801 Quads of direct energy consumption, 0.408 Quads in diesel, 0.128 Quads in gasoline, 0.076 Quads in LP gas, 0.053 Quads in natural gas and 0.135 Quads in electricity[16]. Most large farms use diesel-fueled vehicles for tilling, planting, cultivating, disking, harvesting, and applying chemicals. Table 7 shows the breakdown of diesel fuel consumed. Most tractors and harvesters used fluid power for propulsion (hydraulic rotor motors on the wheels) as well as power for auxiliary equipment (pistons for articulation of buckets, configuration control of equipment). This study shows

\footnotetext{
${ }^{16} \mathrm{See} \mathrm{http://farmindustrynews.com/farm-equipment/0101-tractor-hydraulics-advancement/}$
} 
that fluid power accounts for approximately 0.016 Quads of energy consumed in agriculture and $1.15 \mathrm{MMT}$ of $\mathrm{CO}_{2}$.

Table 7. Agriculture Energy Consumption

\begin{tabular}{|c|c|c|c|c|c|c|}
\hline Equipment & Quantity & Gal/hour & Hours/year & $\begin{array}{l}\text { Total fuel } \\
\text { (gallons) }\end{array}$ & $\begin{array}{l}\text { Percentage to } \\
\text { Hydraulics }\end{array}$ & $\begin{array}{l}\text { Energy } \\
\text { (Quads) }\end{array}$ \\
\hline $\begin{array}{l}\text { Large (>100 hp) } \\
\text { Tractors }\end{array}$ & 35000 & 12.1 & 600 & $2.55 \mathrm{E}+08$ & $14 \%$ & 0.005 \\
\hline $\begin{array}{l}\text { Medium (> } 40 \mathrm{hp}) \\
\text { Tractors }\end{array}$ & 85000 & $\overline{4.2}$ & 800 & $2.88 \mathrm{E}+08$ & $14 \%$ & 0.005 \\
\hline $\begin{array}{l}\text { Small }(<40 \mathrm{hp}) \\
\text { Tractors }\end{array}$ & 130000 & 1.8 & 1000 & $2.36 \mathrm{E}+08$ & $14 \%$ & 0.005 \\
\hline Harvesters & 30000 & 6.1 & 400 & $7.27 \mathrm{E}+07$ & $7 \%$ & $\overline{0.001}$ \\
\hline & & & Total fuel & $3.1 \mathrm{E}+09$ & $\begin{array}{l}\text { Total Energy } \\
\text { (Quads) }\end{array}$ & 0.016 \\
\hline
\end{tabular}

\section{B. INDUSTRIAL HYDRAULICS}

In industrial applications, hydraulics is used to control and strengthen industrial machinery. Applications include bailers and compactors, hydraulic presses, industrial machinery, machine tooling, paper, plastic and rubber processing, pressure diecasting machines, medical equipment, oil and gas refining, and power generation to name a few. Industrial hydraulics is ideal for the harsh environment because of their exceptional tolerance to contamination and high temperatures. In terms of estimating the energy consumed powering industrial hydraulic equipment, the primary industries covered in this survey were the injection molding, blow molding and metal forming equipment. Table 8 shows approximately 103,700 injection molding machines in the United States consuming approximately 0.18 Quads of energy each year. There are approximately 160,000 metal forming machines, shown in Table 9 consuming approximately 0.010 Quads/year. These industries account for $17.3 \%$ of the industrial hydraulics industry. Therefore, the total industrial hydraulics industry consumes approximately 1.10 Quads of energy per year producing approximately 196.12 MMT of $\mathrm{CO}_{2}$. 
Table 8. Injection Molding (IM) and Blow Injection Molding (BIM) Machines

\begin{tabular}{|c|c|c|c|c|c|}
\hline & $\begin{array}{l}\text { Clamp } \\
\text { Force } \\
\text { (Tons) }\end{array}$ & $\begin{array}{c}\text { Number in } \\
\text { Use }\end{array}$ & $\begin{array}{c}\text { Energy } \\
\text { Consumption } \\
\text { (hp) }\end{array}$ & $\begin{array}{l}\text { Energy Consumed } \\
\text { Per Piece to Drive } \\
\text { Fluid Power } \\
\text { System } \\
\text { (percentage) }\end{array}$ & $\begin{array}{c}\text { Total Energy } \\
\text { Consumed for } \\
\text { Fluid Power (Btu) }\end{array}$ \\
\hline \multirow[t]{10}{*}{$\mathrm{IM}$} & 35 & 14500 & 10 & 88 & $1.96 \mathrm{E}+12$ \\
\hline & 55 & 10000 & 18 & 88 & $2.15 \mathrm{E}+12$ \\
\hline & 90 & 9000 & 20 & 88 & $2.15 \mathrm{E}+12$ \\
\hline & 310 & 8000 & 60 & 88 & $5.72 \mathrm{E}+12$ \\
\hline & 450 & 7000 & 75 & 88 & $6.26 \mathrm{E}+12$ \\
\hline & 550 & 6000 & 100 & 88 & $7.15 \mathrm{E}+12$ \\
\hline & 580 & 6000 & 100 & 88 & $7.15 \mathrm{E}+12$ \\
\hline & 725 & 5000 & 100 & 88 & $5.96 \mathrm{E}+12$ \\
\hline & 725 & 5000 & 150 & 88 & $8.94 \mathrm{E}+12$ \\
\hline & 950 & 4000 & 150 & 88 & $7.15 \mathrm{E}+12$ \\
\hline \multirow[t]{5}{*}{ Other Mach. } & 126 & 3000 & 600 & 60 & $2.15 \mathrm{E}+13$ \\
\hline & 141 & 3000 & 700 & 60 & $2.50 \mathrm{E}+13$ \\
\hline & 141 & 2000 & 750 & 60 & $1.79 \mathrm{E}+13$ \\
\hline & 141 & 2000 & 1050 & 60 & $2.50 \mathrm{E}+13$ \\
\hline & 141 & 1500 & 1100 & 60 & $1.97 \mathrm{E}+13$ \\
\hline \multirow[t]{12}{*}{ BIM } & 65 & 1000 & 80 & 50 & $9.54 \mathrm{E}+11$ \\
\hline & 80 & 1000 & 105 & 50 & $1.25 \mathrm{E}+12$ \\
\hline & 90 & 1000 & 130 & 50 & $1.55 \mathrm{E}+12$ \\
\hline & 100 & 1000 & 180 & 50 & $2.15 \mathrm{E}+12$ \\
\hline & 122 & 900 & 100 & 50 & $1.07 \mathrm{E}+12$ \\
\hline & 189 & 800 & 125 & 50 & $1.19 \mathrm{E}+12$ \\
\hline & 75 & 1500 & 75 & 50 & $1.34 \mathrm{E}+12$ \\
\hline & 90 & 1500 & 150 & 50 & $2.68 \mathrm{E}+12$ \\
\hline & 600 & 2000 & 30 & 50 & $7.15 \mathrm{E}+11$ \\
\hline & 800 & 2000 & 30 & 50 & $7.15 \mathrm{E}+11$ \\
\hline & 1000 & 2500 & 60 & 50 & $1.79 \mathrm{E}+12$ \\
\hline & 1600 & 2500 & 60 & 50 & $1.79 \mathrm{E}+12$ \\
\hline Total & & 103700 & & & $1.81 \mathrm{E}+14$ \\
\hline
\end{tabular}

Table 9. Metal Forming Machines

\begin{tabular}{|c|c|c|c|c|c|}
\hline $\begin{array}{c}\text { Number in } \\
\text { Use }\end{array}$ & $\begin{array}{c}\text { Average Energy } \\
\text { Consumption } \\
\text { (hp) }\end{array}$ & $\begin{array}{c}\text { Average } \\
\text { yearly use } \\
\text { (hrs/year) }\end{array}$ & $\begin{array}{c}\text { Energy } \\
\text { Consumed Per } \\
\text { Piece to Drive } \\
\text { Fluid Power } \\
\text { System } \\
\text { (percentage) }\end{array}$ & $\begin{array}{c}\text { Total Energy } \\
\text { Consumed for } \\
\text { Fluid Power } \\
\text { (Btu) }\end{array}$ & $\begin{array}{c}\text { Current } \\
\text { Fluid Power } \\
\text { System } \\
\text { Efficiency }\end{array}$ \\
\hline 159938 & $\mathbf{3}$ & 47679840 & $\mathbf{5 0}$ & $\mathbf{8 . 6 7 E + 1 2}$ & $\mathbf{5 0 \%}$ \\
\hline
\end{tabular}




\section{PNEUMATICS}

Pneumatics, like hydraulics, is pervasive in industry but is based on 1960s' technologies. Pneumatics accounts for a tremendous amount of energy in manufacturing. As an example, Eric Battino, PepsiCo's Sustainability Manager, has identified four primary areas that consume more than $60 \%$ of their energy: combustion, steam, refrigeration and compressed air/pneumatics. According to Mr. Battino, internal studies at PepsiCo show that compressed air and pneumatics accounts for $10 \%$ of their total energy (combined fuel and electricity) across all of PepsiCo's manufacturing plants. Seventy percent of all manufacturing facilities in the United States have some form of compressed air systems. Most of these systems provide compressed air to drive a variety of equipment including machine tools, manufacturing and material handling equipment [17]. A recent internal analysis based on data from the DOE's Compressed Air Challenge of more than 203,000 industrial plants using pneumatics, shows a potential annual savings of $\$ 2.34 \mathrm{~B}$ in electricity costs through optimization of plant air production and productivity enhancements. This report assumed $\$ 0.08 / \mathrm{kWh}$ energy cost. Therefore, this energy savings is equivalent to 0.10 Quads. Furthermore, the internal report states that these direct improvements using today's technologies account for only $25 \%$ of the known losses suggesting a total loss of 0.40 Quads due to inefficiencies in pneumatic systems. Today, the typical efficiency for industrial pneumatic systems is between $12 \%$ and $17 \%$ [6]. Therefore, a conservative estimate of the total energy devoted to pneumatics is 0.47 Quads/year assuming these losses account for $85 \%$ of the total energy devoted to pneumatics (given an average efficiency of $15 \%$ ).

A second estimate for energy consumed driving pneumatics is based on percentages of compressed gas used in individual industries. Table 10 shows the energy consumed in each subsector, the percentage of electricity devoted to compressed air and pneumatics and the subsequent energy consumed driving pneumatic products resulting in a total of 2.63 Quads of energy in 2008. Energy use was updated based on the latest information available from the U.S. Energy Information Administration. The percentages for each sector is based on a study conducted by ORNL and XENERGY, Inc. on the compressed air market in 2001 [17]. According to this study, compressed air systems account for $10 \%$ of all electricity and roughly $16 \%$ of all motor system energy use in the U.S. manufacturing industries. 
Table 10. Compressed Air and Pneumatics Energy Use

\begin{tabular}{|c|l|c|c|c|}
\hline $\begin{array}{l}\text { NAICS } \\
\text { Code }\end{array}$ & Subsector and Industry & $\begin{array}{c}\text { Total } \\
\text { Quads })\end{array}$ & $\begin{array}{c}\text { \% Electric for } \\
\text { Pneumatics }\end{array}$ & $\begin{array}{c}\text { Pneumatic Energy } \\
\text { (Quads) }\end{array}$ \\
\hline 311 & Food & 1.186 & $4.50 \%$ & 0.053 \\
\hline 313 & Textile Mills & 0.178 & $7.20 \%$ & 0.013 \\
\hline 315 & Apparel & 0.014 & $5.10 \%$ & 0.001 \\
\hline 316 & Leather and Allied Products & 0.003 & $0.20 \%$ & 0.000 \\
\hline 321 & Wood Products & 0.451 & $8.70 \%$ & 0.039 \\
\hline 322 & Paper & 2.354 & $3.70 \%$ & 0.087 \\
\hline 323 & Printing and Related Support & 0.085 & $2.50 \%$ & 0.002 \\
\hline 324 & Petroleum and Coal Products & 6.864 & $15.90 \%$ & 1.091 \\
\hline 325 & Chemicals & 5.149 & $20.10 \%$ & 1.035 \\
\hline 326 & Plastics and Rubber Products & 0.337 & $10.90 \%$ & 0.037 \\
\hline 327 & Nonmetallic Mineral Products & 1.114 & $1.60 \%$ & 0.018 \\
\hline 331 & Primary Metals & 1.736 & $8.30 \%$ & 0.144 \\
\hline 332 & Fabricated Metal Products & 0.396 & $5.20 \%$ & 0.021 \\
\hline 333 & Machinery & 0.204 & $3.60 \%$ & 0.007 \\
\hline 335 & Elec. Equip., Appliances, and Comp. & 0.103 & $9.10 \%$ & 0.009 \\
\hline 336 & Transportation Equipment & 0.477 & $14.00 \%$ & 0.067 \\
\hline 337 & Furniture and Related Products & 0.061 & $6.90 \%$ & 0.004 \\
\hline 339 & Miscellaneous & 0.066 & $10.00 \%$ & 0.007 \\
\hline & & $\mathbf{2 0 . 7 7 8}$ & Total (Quads) & $\mathbf{2 . 6 3 5}$ \\
\hline
\end{tabular}

However, not all of this energy is devoted to performing mechanical work through pneumatic pistons and motors. Removing these industries (petroleum, coal and chemicals) reduces the overall energy associated with pneumatics down to 0.51 Quads/year, very close to our previous estimate. Therefore, we estimate that between 0.47 and 0.51 Quads/year of electricity are used driving pneumatic equipment. The emissions, assuming the primary source of energy is electricity, is between 84.12 and $91.11 \mathrm{MMT} \mathrm{CO}_{2} /$ year.

\section{AEROSPACE}

The U.S. aircraft parts manufacturing industry includes about 1000 companies with a combined annual revenue of $\$ 65 \mathrm{~B} .{ }^{17}$ The engine and engine parts segment accounts for more than half the industry revenue. The 50 largest companies account for nearly $90 \%$ of industry revenues. Manufacturers specialize in producing parts for one or several major systems including the engine, fuselage, propellers and rotors, landing gear, electrical and hydraulic control system and avionics. The aircraft industry has two primary segments: passenger and cargo. The U.S. Department of Transportation estimates that passenger air transport consumed 18,854 million gallons of fuel totaling 2.393 Quads of energy and producing $200 \mathrm{MMT}$ of $\mathrm{CO}_{2}$ in 2008 (Table 2.6 in the Transportation Energy Databook). Cargo accounted for 15,146 million ton-miles of freight. Fuel efficiency for freight is measured in Btu/ton-mile.

Hydraulics and pneumatics is vital for the aerospace industry in terms of flight control surfaces and landing gear. The primary energy concern for the aerospace industry is not the

\footnotetext{
${ }^{17} \mathrm{http}: / / \mathrm{www}$. business wire.com/news/home/20101124005244/en/Research-Markets-Aircraft-PartsManufacturing-Report-50
} 
amount of energy it takes to drive the fluid power systems but how much energy it takes to transport the equipment. We assume that the hydraulic components on a typical aircraft account for a percentage of the total loaded aircraft weight. In one study, the hydraulics weighed $2367 \mathrm{lbs}$ for an aircraft with a total gross weight of 49,000 lbs [18]. Another study of the Boeing YC-14 recorded the aircraft gross weight of 170,000 lbs with $7200 \mathrm{lbs}$ devoted to the hydraulic system [19]. A study, conducted by the NASA for the All Electric Aircraft Program, estimated that embedded hydraulic components accounted for $9.5 \%$ of the fuel used on an aircraft [14]. Table 11 lists a series of aircraft with their total average weight and weight associated with the hydraulic and pneumatic systems. On the average, fluid power components account for $0.98 \%$ of the weight of an aircraft. Therefore, a first approximation of the energy and emissions due to the transport of embedded fluid powered components in U.S. aircraft is 0.024 Quads with 1.71 MMT of $\mathrm{CO}_{2}$.

Table 11. Aircraft Weight Distribution

\begin{tabular}{|c|c|c|c|}
\hline Aircraft & Average Weight (lb) & $\begin{array}{l}\text { Hydraulic and Pneumatic } \\
\text { System Wt (lb) }\end{array}$ & Percentage \\
\hline $727-200$ & $\begin{array}{r}135347.5 \\
\end{array}$ & $\begin{array}{rr} \\
\end{array}$ & $0.85 \%$ \\
\hline $707-320$ & 218690.5 & 1557 & $0.71 \%$ \\
\hline DC-8-55 & 229235.5 & 2250 & $0.98 \%$ \\
\hline DC-8-62 & 235532.5 & $17 \overline{1744}$ & $0.74 \%$ \\
\hline DC-10-10 & 328375 & 4150 & $1.26 \%$ \\
\hline L-1011 & 329507 & 44401 & $1.34 \%$ \\
\hline DC-10-40 & 407367.5 & 4346 & $1.07 \%$ \\
\hline \multirow[t]{2}{*}{747} & 554731.5 & 5067 & $0.91 \%$ \\
\hline & & Average & $0.98 \%$ \\
\hline
\end{tabular}




\section{REFERENCES}

[1] N. Manring, Hydraulic Control Systems, John Wiley and Sons, Inc., 2005.

[2] I. Bush-Vishnai, Electromechanical Sensors and Actuators, Springer-Verlag, New York, 1998.

[3] A. Dorey and J. Moore, Advances in Actuators, IOP Publishing, 1995.

[4] M. Gandhi and B. Thompson, Smart Materials and Structures, Chapman \& Hall, 1992.

[5] X. Liang and T. Virvalo: What's wrong with energy utilization in hydraulic cranes; IHA, Tampere University of Technology, Tampere, Finland.

[6] G. Belforte, "New Developments and New Trends in Pneumatics," keynote lecture for FLUCOME 2000, 6th International Symposium on Flow Control, Canada, 2000.

[7] Murrenhoff, H., "Trends and some recent developments in mobile hydraulics," ftp://ftp.ifas.rwth-

aachen.de/Veroeffentlichungen/Mh_Trends_and_some_recent_developments_in_Mobile_Hy draulics.pdf

[8] J. Palmberg, M Rosth, "Mode Switching and Energy Recuperation in Open-Circuit Pump Control," The 10th Scandinanvian International Conference on Fluid Power, Tampere, Finland, 2007.

[9] T. Ho and K. Ahn, "Saving Energy Control of Cylinder Drive Using Hydraulic Transformer Combined with an Assisted Hydraulic Circuit," ICROS-SICE International Joint Conference, 2009.

[10] P. Achten, T. Brink, J. Potma, M Schellekens and G. Vael, "A Four-Quadrant Hydraulic Transformer for Hybrid Vehicles," The $11^{\text {th }}$ Scandinavian International Conference on Fluid Power, Sweden, 2009.

[11] X. Luo, H. Sun and J. Wang, "An Energy Efficiency Pneumatic-electrical System and Control Strategy Development," Amercian Control Conference, 2011.

[12] B. Ban Batavia, "Hydraulic Hybrid Vehicle Energy Management System, SAE Technical Paper 2009-01-2834, 2009.

[13] P. Alles and E. Lanke, "NFPA Customer Market Survey: 2009 Data," National Fluid Power Association, 2009.

[14] C. Spitzer, "The All-Electric Aircraft: A Systems View and A Proposed NASA Research Program," IEEE Transactions on Aerospace and Electronic Systems, Vol. AES-20, No.3, pp. 261-266, May 1984.

[15] S. Davis and L. Truett, "Off-Highway Transporation Related Fuel Use," ORNL/TM-2004/92.

[16] U.S. Agriculture and Forestry Greenhouse Gas Inventory, 1990-2005, pp. 85, http://www.usda.gov/oce/climate_change/AFGG_Inventory/5_AgriculturalEnergyUse.pdf

[17] Assessment of the market for Compressed Air Efficiency Services, Report by XENERGY and ORNL for DOE Office of Industrial Technologies, June 2001.

[18] T. Boldt, C. Chenoweth, I. Mehdi, E. Raymond, L. Witonsky and R. Yurczyk, "Airplane Actuation Trade Study," AFWAL-TH-81-3153, Jan. 1982.

[19] E. Raymond, "Design Guide for Aircraft Hydraulic Systems and Components for Use with Chlorotrifluouroethylene Nonflammable Hydraulic Fluids," AFWAL-TR-80-2011, March 1982. 


\section{INTERNAL DISTRIBUTION}
1. L. J. Love
5. C. A. Blue
2. F. G. Pin
6. R. D. Ott
3. K. W. Tobin
7. R. F. Lind
4. M. Keller

\section{EXTERNAL DISTRIBUTION}

1. E. Lanke, National Fluid Power Association, 3333 North Mayfair Road, Suite 211, Milwaukee, WI 53222

2. P. Alles, National Fluid Power Association, 3333 North Mayfair Road, Suite 211, Milwaukee, WI 53222

3. L. Christodoulou, Advanced Manufacturing Office, Energy Efficiency and Renewable Energy, U.S. Department of Energy, EE-25, 100 Independence Ave., SW, Washington, DC 20585-012

4. S. Sikirica, Advanced Manufacturing Office, Energy Efficiency and Renewable Energy, U.S. Department of Energy, EE-25, 100 Independence Ave., SW, Washington, DC 20585-0121

5. I. Chan, Advanced Manufacturing Office, Energy Efficiency and Renewable Energy, U.S. Department of Energy, EE-25, 100 Independence Ave., SW, Washington DC 20585-012

6. K. Stelson, Dept. of Mechanical Engineering, University of Minnesota, 111 Church Street S.E., Minneapolis, MN 55455

7. M. Ivantysynova, School of Mechanical Engineering, Purdue University, 1500 Kepner Drive, Lafayette, IN 47905 